\title{
Multiple Roles of Autophagy in the Sorafenib Resistance of Hepatocellular Carcinoma
}

\author{
Ting Sun Hongchun Liu Liang Ming
}

Key Clinical Laboratory of Henan Province, Department of Clinical Laboratory, The First Affiliated Hospital of Zhengzhou University, Zhengzhou, China

\section{Key Words}

Hepatocellular carcinoma • Sorafenib • Autophagy • Drug resistance

\begin{abstract}
Hepatocellular carcinoma (HCC) is the second leading cause of cancer-related death worldwide, and prognosis remains unsatisfactory since the disease is often diagnosed at the advanced stages. Currently, the multikinase inhibitor sorafenib is the only drug approved for the treatment of advanced HCC. However, primary or acquired resistance to sorafenib develops, generating a roadblock in HCC therapy. Autophagy is an intracellular lysosomal pathway involved in protein and organelle degradation, with an astonishing number of connections to human disease and physiology. Current understanding of the role of autophagy in the progression of cancer and the response to cancer therapy remains controversial. Sorafenib is able to induce autophagy in HCC, but the effect of autophagy is indistinct. Some studies established that sorafenib-induced autophagy serves as a pro-survival response. However, other studies found that sorafenib-induced autophagy improves the lethality of sorafenib against HCC cells. The mechanisms underlying autophagy and sorafenib resistance remain elusive. The purpose of this review is to summarize the progress of research focused on autophagy and sorafenib resistance and to update current knowledge of how cellular autophagy impacts sorafenib sensitivity in HCC treatment.
\end{abstract}

\section{Introduction}

Liver cancer is a major health problem and a primary cause of cancer-related death worldwide, only second to lung cancer. Hepatocellular carcinoma (HCC), the most common type of liver cancer, is the fifth most commonly diagnosed cancer and the second most common cause of cancer deaths worldwide [1]. HCC commonly develops in patients with underlying chronic liver inflammation related to viral infection, alcohol intake, or metabolic syndrome [2,3]. The recommended treatment of HCC patients depends on general status 
of the patient, assessment of current liver function, tumor size, vascular invasion, and the presence of extrahepatic metastasis. Despite remarkable progress in the prevention, diagnosis, and treatment of HCC throughout the last several decades, there is still no sufficiently effective treatment due to late-stage diagnosis and inadequate clinical strategies for inhibiting metastasis [4]. Potentially curative treatments such as surgical resection and liver transplantation may be available for patients diagnosed at early stage [5]. For patients with advanced HCC, only palliative treatments are available, and sorafenib is the only choice of systemic therapy $[6,7]$.

Sorafenib (BAY 43-9006, Nexavar®), an oral multikinase inhibitor, remains the only FDAapproved systemic drug for patients with advanced HCC [8-10]. Sorafenib was approved for the treatment of patients with advanced HCC on the basis of two international randomized, controlled trials (RCTs), the SHARP (Sorafenib HCC Assessment Randomized Protocol) and the Asia-Pacific trials $[11,12]$. The SHARP trial, conducted in western countries, was a multicenter, phase III, double-blind study, in which 602 HCC patients who had not received any previous systemic treatment were assigned to receive sorafenib $400 \mathrm{mg}$ bis in die (bid) or placebo. Sorafenib prolonged the median overall survival (OS) to 10.7 months versus 7.9 months in the placebo group [11]. In the Asia-Pacific trials, 226 patients with HCC were randomized to receive sorafenib $400 \mathrm{mg}$ bid or placebo. In the sorafenib group, the median OS was 6.5 months, compared with 4.2 months in the placebo group [12]. It is worth noting that, patients in the SHARP trial were mostly of Caucasian ethnicity and had a high prevalence of HCV infection; conversely, patients in the Asia-Pacific trial were more largely infected by HBV and presented a more advanced stage of HCC and a worse liver function. These differences can explain the difference in OS observed between the two trials.

Sorafenib suppresses tumor angiogenesis and proliferation by inhibiting serine/ threonine kinases and receptor tyrosine kinases [13]. Sorafenib displays a remarkable inhibition of the RAF/MEK/ERK and p38/MAPK signaling pathways [14, 15] and also suppresses other receptor tyrosine kinases such as VEGFR (vascular endothelial growth factor receptor), PDGFR (platelet-derived growth factor receptor), FLT-3 (FMS-like tyrosine kinase 3) and FGFR-1 (fibroblast growth factor receptor-1) [16, 17].

Nevertheless, a considerable number of HCC patients are refractory to sorafenib treatment. Sorafenib is beneficial in only approximately $30 \%$ of patients, and acquired resistance often develops within 6 months $[11,12]$, suggesting the existence of primary and acquired sorafenib resistance in HCC cells. Sorafenib resistance is mediated through multiple factors that have not been thoroughly investigated. It is thought to be largely due to upregulation of survival pathways that may neutralize the death signals induced by sorafenib. Therefore, a better knowledge of these cellular pathways is required to overcome tumor resistance and consequently improve the effects of sorafenib therapy [18-20].

\section{Autophagy and cancer}

Autophagy is an evolutionarily conserved process in which damaged or useless organelles, proteins or other cytoplasmic components are delivered to lysosomal system for degradation [21-23]. It has been characterized as an adaptive catabolic process that is essential for maintaining cellular homeostasis [24, 25]. Various stimuli, such as nutrient deprivation, growth factor withdrawal, hypoxia or drug treatment, have the ability to induce autophagy [26]. Autophagic process involves a highly conserved group of genes which were discovered in yeasts and named as autophagy-related genes (Atgs) (Fig. 1) [27-29]. Autophagy is initiated by the ULK1-Atg13-FIP200 complex [30]. Next, Beclin1-Vps34Atg14 complex contributes to membrane nucleation and elongation [31, 32]. Besides, two ubiquitin-like systems, Atg5-Atg12-Atg16 and LC3, are both required for elongation of the autophagosome membrane. Closure of the autophagosome is dependent on the activity of the LC3-conjugation system [33]. In most cases, the formed autophagosomes merge with endocytic pathway and then fuse with lysosomal compartment. These steps are collectively 


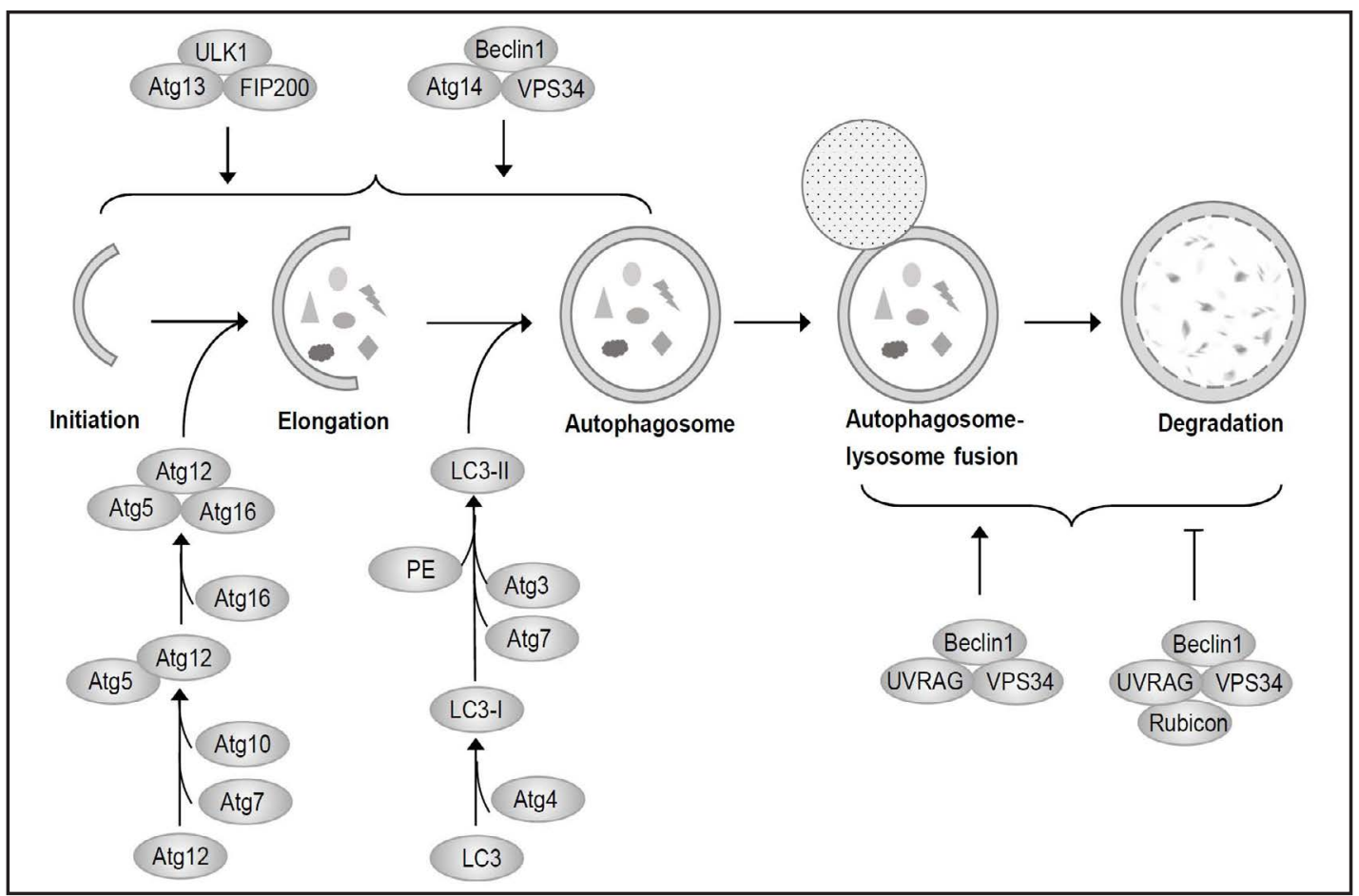

Fig. 1. Schematic model of autophagy flux.Autophagy is initiated by the nucleation of an isolation membrane or phagophore (Initiation). The process is initiated by the ULK1-Atg13-FIP200 complex. This membrane then elongates to engulf cytoplasmic components (Elongation). Beclin 1: Vps34: Atg14 complex contributes to the formation of an isolation membrane and elongation. Elongation of the phagophore membrane is dependent on the Atg5-Atg12-Atg16 and LC3 conjugation systems. LC3-II localizes to the elongated isolation membrane at the latter step of autophagosome formation, while the Atg5-Atg12-Atg16 complex dissociates from it. Closure of the autophagosome is dependent on LC3- II. Finally, the isolation membrane is enclosed to form an autophagosome. After autophagosome formation, the lysosome fuses with the autophagosome to form an autolysosome (Autophagosome-lysosome fusion). Intra-autophagosome contents are degraded by lysosomal hydrolases (Degradation). The Beclin 1:hVps34:UVRAG complex positively regulates the fusion and degradation. When associated with Rubicon, it inhibits autophagic degradation.

termed maturation. The Beclin1-Vps34-UVRAG complex positively regulates the maturation of autophagosomes and endocytic trafficking. When associated with Rubicon, the complex blocks autophagosome maturation $[34,35]$. Different signaling pathways participate in autophagy regulation. The most important pathways are related to mTORC1 (mammalian target of rapamycin complex 1) and AMPK (5'AMP-activated protein kinase). mTORC1 abolishes autophagy in the presence of abundant nutrients or growth factors through inhibition of ULK1, while AMPK induces autophagy when cellular energy is insufficient [36, 37].

Autophagy acts as a double-edged sword in cancer cells [38, 39]. Basal autophagy acts as a tumor suppressor by maintaining genomic stability in normal cells. Once cancer has been established, activated autophagy will contribute to cancer cell survival under stress and in turn promote cancer development [40-43]. Studies have indicated that, in different cancers, autophagy appears to serve as either a pro-survival or pro-death response. Autophagy is also considered as an important mechanisms of drug resistance by supporting the survival of tumor cells under metabolic and therapeutic stress. During cancer treatment, including radiation, chemotherapy and target therapy, autophagy is usually activated [44]. Thus, further studies of autophagy and sorafenib is highly valuable in cancer treatment, and resistance to sorafenib must be resolved to improve sorafenib efficiency and HCC treatment. 


\section{Cellular Physiology Cell Physiol Biochem 2017;44:716-727 \begin{tabular}{l|l|l} 
DOI: 10.1159/000485285 & $\begin{array}{l}\text { O } 2017 \text { The Author(s). Published by S. Karger AG, Basel } \\
\text { www.karger.com/cpb }\end{array}$
\end{tabular} \\ Sun/Liu/Ming: Autophagy and Sorafenib Resistance in HCC}

Table 1. Sorafenib-induced autophagy in HCC

\begin{tabular}{|c|c|c|c|}
\hline Cell line & Related signaling pathway & Effects on autophagy and cancer & References \\
\hline $\begin{array}{l}\text { MHCC97-L, } \\
\text { PLC/PRF/5, } \\
\text { HepG2 }\end{array}$ & $\begin{array}{l}\text { IRE1 signaling pathway of ER } \\
\text { stress }\end{array}$ & $\begin{array}{l}\text { Inducing autophagy and alleviating the } \\
\text { ER stress-induced cell death. }\end{array}$ & {$[45]$} \\
\hline HepG2, Huh7 & $\begin{array}{l}\text { Activating Akt via the feedback } \\
\text { loop of mTOR }\end{array}$ & $\begin{array}{l}\text { Inducing autophagy and resistance to } \\
\text { sorafenib }\end{array}$ & [46] \\
\hline $\begin{array}{l}\text { Huh7, HLF, } \\
\text { PLC/PRF/5 }\end{array}$ & Inhibiting mTORC1 & $\begin{array}{l}\text { Inducing autophagy and resistance to } \\
\text { sorafenib }\end{array}$ & [47] \\
\hline $\begin{array}{l}\text { PLC5, HepG2 } \\
\text { Sk-Hep1, Нер3B }\end{array}$ & $\begin{array}{l}\text { Releasing Beclin } 1 \text { from binding } \\
\text { with Mcl-1 }\end{array}$ & Inducing autophagic cell death & [48] \\
\hline Hep3B, Huh7 & $\begin{array}{c}\text { Activating AMPK and } \\
\text { consequently autophagy in } \\
\text { Huh7, but not in Hep3B cells. }\end{array}$ & $\begin{array}{l}\text { Different autophagy responsiveness to } \\
\text { sorafenib might be linked to generation } \\
\text { of sorafenib resistance. }\end{array}$ & [49] \\
\hline
\end{tabular}

\section{Sorafenib induces autophagy in HCC}

Sorafenib is a multi-kinase inhibitor that targets multiple genes that modulate the cellular survival, proliferation and metastasis of cancer. Studies have shown that sorafenib treatment enhances autophagy in HCC cells (Table 1). Shi et al. found that sorafenib induced both apoptosis and autophagy in human HCC cells through upregulation of IRE1 signals that involves endoplasmic reticulum (ER) stress [45]. Sorafenib can also induce autophagy through activating Akt pathway or inhibiting mTORC1 [46, 47]. Moreover, according to the study by Tai et al., sorafenib activated autophagy through releasing Beclin 1 from binding with Mcl-1 [48].

It is obvious that autophagy is responsible for orchestrating adaptive responses to sorafenib in HCC. However, the effect of autophagy is indistinct. Some studies have established that sorafenib induces the activation of protective autophagic responses in HCC cells. Inhibition of autophagy using either pharmacological inhibitors (chloroquine, 3-MA or bafilomycin A1) or essential autophagy gene (Beclin1 or Atg5) knockdown enhances the cytotoxicity of sorafenib against HCC cells, indicating that autophagy induced by sorafenib acts as a protective pathway [45-47, 50, 51]. Patients with higher Atg7 expression and autophagy activity have a poorer prognosis for sorafenib treatment [52]. However, not all sorafenib-induced autophagy serves as a pro-survival response, and other studies have observed opposite results in HCC. Studies have reported that sorafenib-induced autophagy improves the lethality of sorafenib against HCC cells [48]. Furthermore, various HCC cell lines exhibit different sensitivity to sorafenib might due to different autophagy responsiveness to sorafenib [49].

Animal models are viewed as crucial tools in the study of cancer. To clarify the pathogenesis of HCC and investigate the effects of potential therapies, a number of animal models have been developed. Considered as an uncontrollable and unpredicted system, with an extremely low incidence rate, spontaneous HCC models are scarcely used nowadays. Subcutaneous xenograft models are widely used in the past few decades. Development of transgenic and gene targeting technologies facilitated the generation of genetically engineered mouse models (GEM), which have greatly facilitated studies of gene function in HCC development. The most common ways to generate mouse models of HCC are activating oncogenes (such as Ras, HBx, c-Met, c-Myc or AKT) or inactivating tumor-suppressor genes ( $\mathrm{p} 53, \mathrm{Rb})$, or both in vivo through the use of transgenic and gene-targeting approaches [53-58]. Moreover, chemically induced hepatocarcinogenesis in animals share many of the morphological, histogenic, and biochemical features of human HCC, which begin with an irreversible process characterized by structural DNA changes [59]. Diethylnitrosamine (DEN), carbon tetrachloride (CCl4), aflatoxine, dimethylnitrosamine (DMN) and thioacetamide are common hepatic carcinogens. Among them, DEN-induced HCC model is the most frequently used $[60,61]$. A recent study have demonstrated that autophagy inhibits HCC progression and sorafenib resistance by promoting degradation of HIF1 $\alpha$ in the DEN-induced HCC mouse model [62]. 


\section{Cellular Physiology Cell Physiol Biochem 2017;44:716-727 \begin{tabular}{ll|l} 
and & DOI 10.1159/000485285 & $\begin{array}{l}\text { O 2017 The Author(s). Published by S. Karger AG, Basel } \\
\text { www.karger.com/cpb }\end{array}$ \\
\cline { 2 - 3 }
\end{tabular} \\ Sun/Liu/Ming: Autophagy and Sorafenib Resistance in HCC}

The pathways involved in sorafenib-mediated autophagy regulation

There are many proteins and pathways that are involved in sorafenib-mediated autophagy regulation in HCC cells (Fig. 2). mTORC1 is a highly conserved serine/threonine kinase complex and a key negative regulator of autophagy $[63,64]$. Some researchers have assessed the role of mTORC1 suppression in sorafenib-induced autophagy in HCC [47]. p70S6K and 4E-BP1 are proteins downstream of mTORC1 [65]. Furthermore, sorafenib is able to dephosphorylate p70S6K and 4E-BP1 in HCC cells and in HCC xenograft models, indicating an inhibition of mTORC1 activity [66]. The PI3K/Akt signaling pathway is a major upstream inducer of mTORC1. Studies have shown that activation of PI3K/Akt signaling pathway mediates acquired resistance to sorafenib in HCC cells [67]. Furthermore, another study demonstrated that inhibition of Akt reverses acquired resistance to sorafenib by switching protective autophagy to autophagic cell death in HCC [46].

AMPK is an important energy sensor in cells [68, 69]. AMPK can initiate autophagy through inactivation of mTORC1 or by phosphorylation of ULK1 [70, 71]. It is possible that sorafenib activates AMPK by inducing cellular ATP reduction and a corresponding increase in the AMP/ATP ratio [72, 73]. Curiously, there are differences in sorafenib-dependent modulation of AMPK in HCC cell lines, where AMPK and consequently autophagy were activated in Huh7, but not in Hep3B cells. Hep3B cells were significantly more resistant to sorafenib than Huh7 cells [49]. Therefore, different autophagy responsiveness to sorafenib might be linked to generation of sorafenib resistance. Nevertheless, the AMPK pathway may be not involved in sorafenib-induced autophagy, since LC3-II was still upregulated significantly when AMPK was inhibited in HCC cells cultured with sorafenib $[73,74]$.

Beclin1 is a very important protein in autophagy initiation [31, 75]. Beclin1 contains a BH3 domain which binds to multiple antiapoptotic proteins belonging to the Bcl-2 family, such as Bcl-2, Bcl-xL, or Mcl-1 [76]. This interaction represses Beclin1 activity and significantly reduces initiation of autophagy. When the BH3 domain is phosphorylated, there is decreased binding affinity between these two proteins, resulting in Beclin 1 release and its subsequent activation [76, 77]. A study found that sorafenib reduces the phosphorylation of STAT3, which subsequently reduces the downstream gene Mcl-1 expression. As a result, the Mcl-1-Beclin1 interaction was disrupted, inducing the release of Beclin1 and the formation of new autophagosomes [48]. It demonstrated that sorafenib activates autophagy in HCC cells through the STAT3-Mcl-1-Beclin1 pathway [48].

\section{Other genes promoting sorafenib resistance through regulating autophagy}

A study explored the mechanism of PSMD10-induced autophagy in sorafenib resistance. Increased expression of PSMD10 and Atg7 is a marker of poor prognosis in HCC patients receiving sorafenib treatment. PSMD10 is physically associated with Atg7 in the cytoplasm. Further study found that PSMD10 translocates to the nucleus and binds cooperatively with nuclear HSF1 (heat shock transcription factor 1) onto the Atg7 promoter to initiate its transcription [52]. Therefore, PSMD10 promotes autophagic flux and sorafenib resistance in HCC treatment and inhibition of autophagy could effectively reverse sorafenib resistance enhanced by PSMD10 [52].

Another report demonstrated that ADRB2 promotes sorafenib resistance by inhibition of autophagic degradation of HIF1 $\alpha$. ADRB2 signaling negatively regulates autophagy by disrupting the Beclin1-VPS34-Atg14 complex in an Akt-dependent manner. Autophagy inhibition by ADRB2 leads to stabilization of HIF1 $\alpha$ and the acquisition of resistance to sorafenib. Conversely, inhibition of ADRB2 leads to enhanced autophagy, HIF1 $\alpha$ destabilization, and an improved anti-tumor activity of sorafenib. These results uncover an important role of ADRB2 signaling in sorafenib resistance through inhibition of autophagy [62].

MicroRNAs involved in autophagy and sorafenib resistance

MicroRNAs (miRNAs) are single-strand, small noncoding ( $\sim 20 \mathrm{nt})$ RNA molecules that bind to the 3'-untranslated region (3'UTR) of target genes and regulate their expression 
Fig. 2. Pathways involved in sorafenib-mediated autophagy in HCC.Sorafenib induces AMPK pathway through increasing the AMP/ATP ratio, then initiates autophagy through inhibiting mTORC1 or by activating ULK1. mTORC1 can be inhibited by sorafenib through the ERK pathway. However, mTORC1 can also be activated by sorafenib through activating Akt. Sorafenib stimulates ER stress, which induces autophagosome formation. It

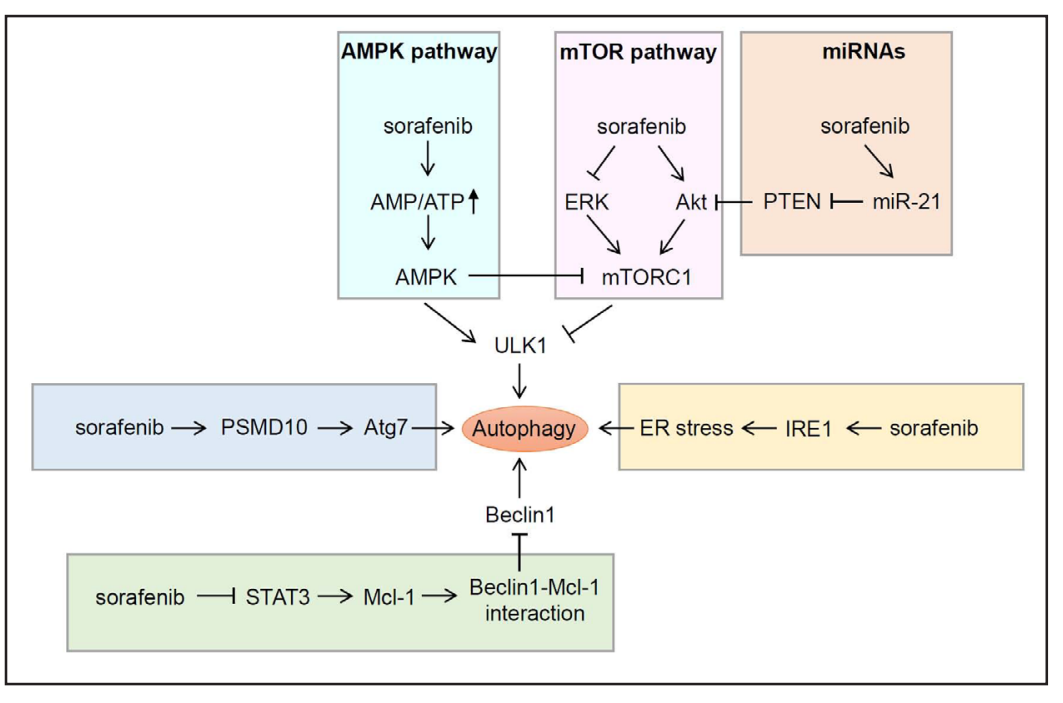
may also disrupt Beclin1-Mcl-1 complex through inhibiting STAT3, releasing Beclin1 to activating autophagy. Sorafenib promotes PSMD10 translocating to the nucleus and initiates Atg7 transcription and autophagy. miRNAs can also be involved in sorafenib-mediated autophagy regulation. Sorafenib increases expression of miR-21, which suppresses autophagy through downregulating PTEN expression and sequential Akt activation. $\rightarrow$, positive regulation or activation; $\dashv$, negative regulation or blockade.

at the post-transcriptional level [78]. MiRNAs participate in multiple biological processes, including autophagy [79-81]. Recent studies have shown that miR-423-5p is upregulated in serum of HCC patients treated with sorafenib and higher expression of secretory miR423-5p is correlated with an improved prognosis. Further experiments demonstrated that miR-423-5p regulates cell cycle progression and enhances autophagy flux. These data suggest that miR423-5p can be used as a useful tool to predict response to sorafenib treatment among HCC patients [82]. Another study showed that exposure of HCC cells to sorafenib leads to increased expression of miR-21. MiR-21 suppresses autophagy through downregulating PTEN expression and sequential Akt activation. Transfection of miR-21 mimics results in restored sorafenib resistance by inhibiting autophagy in HCC cells. These results demonstrated that miR-21 mediates sorafenib resistance of HCC cells by inhibiting autophagy via the PTEN/Akt pathway [83]. They also suggest that miR-21 could serve as a therapeutic target for overcoming sorafenib resistance in the treatment of HCC.

In summary, miRNAs are able to mediate autophagy in response to sorafenib and change the outcome of sorafenib treatment. They might also be predictors of the response of HCC patients to sorafenib treatment in the future.

Effect of sorafenib combination with other drugs on autophagy in HCC

Combination therapy using different pharmaceuticals has been proven highly effective due to the ability to affect multiple cellular pathways involved in cancer [84, 85]. Many studies have analyzed changes in autophagy modulation and effects on cancer treated with different drugs combination with sorafenib (Table 2).

Chloroquine, a lysosomotropic agent that prevents endosomal acidification, has long been used in the treatment or prevention of malaria [90]. Chloroquine inhibits autophagy as it raises the lysosomal $\mathrm{pH}$, which leads to inhibition of fusion of autophagosome with lysosome and lysosomal protein degradation $[38,91]$. Combination of sorafenib with chloroquine significantly suppressed tumor growth compared with sorafenib alone [45, 47]. Vorinostat is the first histone deacetylases (HDAC) inhibitor to be approved for human clinical use [92]. Vorinostat can sensitize HCC cells to sorafenib treatment by regulating the acetylation level of Beclin1. Autophagy inhibition significantly enhances combination therapy of sorafenib with 


\section{Cellular Physiology Cell Physiol Biochem 2017;44:716-727 \begin{tabular}{ll|l} 
and Biochemistry Published onlıne: November 23, 2016 & $\begin{array}{l}\text { (c) } 2017 \text { The Author(s). Published by S. Karger AG, Basel } \\
\text { www.karger.com/cpb }\end{array}$ \\
\hline
\end{tabular} \\ Sun/Liu/Ming: Autophagy and Sorafenib Resistance in HCC}

Table 2. Combination of sorafenib with another drug modulating autophagy in HCC

\begin{tabular}{|c|c|c|c|}
\hline $\begin{array}{l}\text { Drug combined } \\
\text { with sorafenib }\end{array}$ & mechanism of action & Global effects on cancer & Reference \\
\hline Chloroquine & Inhibiting autophagy degration & \multirow{2}{*}{$\begin{array}{c}\text { more cell death and tumor suppression } \\
\text { increased apoptosis and suppressed } \\
\text { tumor growth }\end{array}$} & {$[45]$} \\
\hline Chloroquine & inhibition of autophagy degration & & [47] \\
\hline Metformin & $\begin{array}{l}\text { Inducing more autophagy } \\
\text { disrupting the } \\
\text { mTORC1/mTORC2 feedback loop }\end{array}$ & $\begin{array}{c}\text { impaired proliferation and tumor } \\
\text { inhibition }\end{array}$ & {$[50]$} \\
\hline & Inhibiting autophagy via & & \\
\hline Vorinostat & $\begin{array}{l}\text { upregulating the acetylation level } \\
\text { of Beclin } 1 .\end{array}$ & apoptosis and cell cycle alterations & {$[51]$} \\
\hline \multirow[t]{2}{*}{ Pemetrexed } & $\begin{array}{l}\text { Inducing more autophagy } \\
\text { through inhibition of AKT, p70 }\end{array}$ & \multirow[t]{2}{*}{$\begin{array}{l}\text { more tumor killing via autophagic cell } \\
\text { death }\end{array}$} & \multirow[t]{2}{*}[86]{} \\
\hline & S6K and/or mTOR & & \\
\hline $\begin{array}{l}\text { Akt inhibitor } \\
\text { GDC0068 }\end{array}$ & $\begin{array}{l}\text { Switching autophagy from a } \\
\text { cytoprotective role to a death- } \\
\text { promoting mechanism via } \\
\text { inhibiting Akt }\end{array}$ & \multirow{4}{*}{$\begin{array}{l}\text { inhibit the proliferation and promote } \\
\text { the apoptosis of HCC cells } \\
\text { enhanced the antitumor activity of } \\
\text { sorafenib by changing the tumor } \\
\text { microenvironment. } \\
\text { escape from doxorubicin-induced } \\
\text { autophagic cell death and thus promote } \\
\text { cancer cell survival. }\end{array}$} & {$[46]$} \\
\hline Arsenic trioxide & $\begin{array}{l}\text { diminishing the increased } \\
\text { activation of Akt by sorafenib }\end{array}$ & & [87] \\
\hline PHY906 & $\begin{array}{l}\text { affect autophagy by increasing } \\
\text { AMPK } \alpha-P \text { and ULK1-S555-P }\end{array}$ & & [88] \\
\hline Doxorubicin & $\begin{array}{l}\text { MEK/ERK counteraction, } \\
\text { stimulation of survival via Akt } \\
\text { and dysregulation of cyclin D1 }\end{array}$ & & [89] \\
\hline
\end{tabular}

vorinostat for HCC [51]. Metformin is the first-line medication for the treatment of type II diabetes [93]. As an activator of AMPK, metformin should potentially induce autophagy [94]. Metformin and sorafenib cooperated to promote apoptosis and autophagy in HCC cells. The metformin and sorafenib combination led to increased cell death and tumor inhibition of HCC, which was partially bridged by disrupting the mTORC1/mTORC2 feedback loop [50]. The antifolate drug pemetrexed (ALIMTA, Lilly) has been approved by the FDA for the treatment of nonsmall cell lung cancer (NSCLC) and has been shown to stimulate autophagy $[95,96]$. Studies noted that pemetrexed interacts with sorafenib to kill a wide variety of tumor cell types in a greater than additive fashion via autophagic cell death [86].

Studies have provided evidences that sustained exposure to sorafenib induces the activation of Akt, which contributes to the resistance to sorafenib in HCC cells. Inhibition of Akt reversed sorafenib resistance by switching cytoprotective autophagy to a death-promoting mechanism in the sorafenib-resistant HCC cells. GDC0068, a novel ATP-competitive panAkt inhibitor, could synergize with sorafenib to suppress the growth of sorafenib-resistant HCC [46]. Arsenic trioxide (ATO) is a currently clinically used anticancer drug and displays its anticancer activity by inhibiting Akt activation. Consequently, ATO potentiates the anticancer activities of sorafenib against HCC by diminishing the increased activation of Akt by sorafenib [87]. Sorafenib has also been combined with PHY906, a four-herb Chinese medicine formula. PHY906 can sensitize nude mice bearing HepG2 xenografts to sorafenib. The mechanism might be related to autophagy and microenvironmental activation [88].

However, not all drugs combination with sorafenib can promote anti-tumor activity of sorafenib. Doxorubicin alone could arrest proliferation and induce autophagic cell death in Hep3B cells. When combination with sorafenib, however, sorafenib facilitated cell cycle progression, increased survival and reduced autophagic cell death. Therefore, sorafenib acts as an antagonist of doxorubicin [89]. 


\section{Cellular Physiology Cell Physiol Biochem 2017;44:716-727 and Biochemistry Published \begin{tabular}{l|l} 
DOI: 10.1159/000485285 & (c) 2017 The Author(s). Published by S. Karger AG, Basel \\
www.karger.com/cpb
\end{tabular}

These studies have provided evidence for clinical investigation of some drugs as potential agents that given in combination with sorafenib acts synergistically for HCC therapy.

\section{Conclusion}

Hepatocellular carcinoma, the most common primary liver tumor, is notoriously resistant to systemic therapies. Sorafenib is the only FDA-approved target drug for advanced HCC, but development of resistance alters the efficiency of sorafenib therapy. Autophagy plays a complex role in cancer occurrence and development and is important in cancer therapy. In this review, we summarize the how sorafenib alters autophagy in HCC cells, and the influence of autophagy in the generation of sorafenib resistance. Sorafenib induces autophagy in HCC, causing either cell death or survival. Additionally, there are diverse cellular pathways involving proteins and miRNAs that influence the final outcome of autophagy in response to sorafenib treatment. Further study is needed to elucidate the relationship between autophagy and sorafenib resistance. Firstly, we should figure out which pathways were involved in sorafenib-induced autophagy and why autophagy was activated to different degrees in different HCC patients. Next, we should clarify why autophagy play different roles in HCC, promoting cell death or survival, and find out the underlying determinants of these different effects. Clarifying these questions will help to increase drug effectiveness and provide more effective treatment options for HCC patients.

\section{Acknowledgements}

This work was supported by the National Natural Science Foundation of China (Grant No. 31501123) and the Youth Innovation Fund of the First Affiliated Hospital of Zhengzhou University.

\section{Disclosure Statement}

The authors have declared that no competing interest exists.

\section{References}

1 Siegel RL, Miller KD, Jemal A: Cancer statistics, 2015 CA Cancer J Clin 2015;65:5-29.

2 Ferlay J, Soerjomataram I, Dikshit R, Eser S, Mathers C, Rebelo M, Parkin DM, Forman D, Bray F: Cancer incidence and mortality worldwide: sources, methods and major patterns in GLOBOCAN 2012 Int J Cancer 2015;136:E359-386.

3 Torre LA, Bray F, Siegel RL, Ferlay J, Lortet-Tieulent J, Jemal A: Global cancer statistics, 2012 CA Cancer J Clin 2015;65:87-108.

4 Giannelli G, Rani B, Dituri F, Cao Y, Palasciano G: Moving towards personalised therapy in patients with hepatocellular carcinoma: the role of the microenvironment. Gut 2014;63:1668-1676.

-5 Lo J, Lau EY, Ching RH, Cheng BY, Ma MK, Ng IO, Lee TK: Nuclear factor kappa B-mediated CD47 up-regulation promotes sorafenib resistance and its blockade synergizes the effect of sorafenib in hepatocellular carcinoma in mice. Hepatology 2015;62:534-545.

6 Dutta R, Mahato RI: Recent advances in hepatocellular carcinoma therapy. Pharmacol Ther 2017;173:106117.

7 Forner A, Llovet JM, Bruix J: Hepatocellular carcinoma. Lancet 2012;379:1245-1255.

8 Llovet JM, Hernandez-Gea V: Hepatocellular carcinoma: reasons for phase III failure and novel perspectives on trial design. Clin Cancer Res 2014;20:2072-2079. 


\section{Cellular Physiology Cell Physiol Biochem 2017;44:716-727

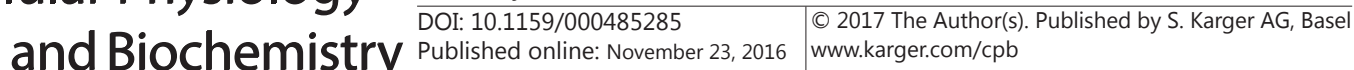

99 Guan YS, He Q: Sorafenib: activity and clinical application in patients with hepatocellular carcinoma. Expert Opin Pharmacother 2011;12:303-313.

10 Colagrande S, Regini F, Taliani GG, Nardi C, Inghilesi AL: Advanced hepatocellular carcinoma and sorafenib: Diagnosis, indications, clinical and radiological follow-up. World J Hepatol 2015;7:1041-1053.

-11 Llovet JM, Ricci S, Mazzaferro V, Hilgard P, Gane E, Blanc JF, de Oliveira AC, Santoro A, Raoul JL, Forner A, Schwartz M, Porta C, Zeuzem S, Bolondi L, Greten TF, Galle PR, Seitz JF, Borbath I, Haussinger D, Giannaris T, Shan M, Moscovici M, Voliotis D, Bruix J, Group SIS: Sorafenib in advanced hepatocellular carcinoma. N Engl J Med 2008;359:378-390.

12 Cheng AL, Kang YK, Chen Z, Tsao CJ, Qin S, Kim JS, Luo R, Feng J, Ye S, Yang TS, Xu J, Sun Y, Liang H, Liu J, Wang J, Tak WY, Pan H, Burock K, Zou J, Voliotis D, Guan Z: Efficacy and safety of sorafenib in patients in the Asia-Pacific region with advanced hepatocellular carcinoma: a phase III randomised, double-blind, placebocontrolled trial. Lancet Oncol 2009;10:25-34.

13 Sanoff HK, Chang Y, Lund JL, O’Neil BH, Dusetzina SB: Sorafenib Effectiveness in Advanced Hepatocellular Carcinoma. Oncologist 2016;21:1113-1120.

14 Adnane L, Trail PA, Taylor I, Wilhelm SM: Sorafenib (BAY 43-9006, Nexavar), a dual-action inhibitor that targets RAF/MEK/ERK pathway in tumor cells and tyrosine kinases VEGFR/PDGFR in tumor vasculature. Methods Enzymol 2006;407:597-612.

15 Liu L, Cao Y, Chen C, Zhang X, McNabola A, Wilkie D, Wilhelm S, Lynch M, Carter C: Sorafenib blocks the RAF/MEK/ERK pathway, inhibits tumor angiogenesis, and induces tumor cell apoptosis in hepatocellular carcinoma model PLC/PRF/5 Cancer Res 2006;66:11851-11858.

16 Auclair D, Miller D, Yatsula V, Pickett W, Carter C, Chang Y, Zhang X, Wilkie D, Burd A, Shi H, Rocks S, Gedrich R, Abriola L, Vasavada H, Lynch M, Dumas J, Trail PA, Wilhelm SM: Antitumor activity of sorafenib in FLT3driven leukemic cells. Leukemia 2007;21:439-445.

-17 Wilhelm S, Carter C, Lynch M, Lowinger T, Dumas J, Smith RA, Schwartz B, Simantov R, Kelley S: Discovery and development of sorafenib: a multikinase inhibitor for treating cancer. Nat Rev Drug Discov 2006;5:835844.

18 Knievel J, Schulz WA, Greife A, Hader C, Lubke T, Schmitz I, Albers P, Niegisch G: Multiple mechanisms mediate resistance to sorafenib in urothelial cancer. Int J Mol Sci 2014;15:20500-20517.

19 Sakai K, Takeda H, Nishijima N, Orito E, Joko K, Uchida Y, Izumi N, Nishio K, Osaki Y: Targeted DNA and RNA sequencing of fine-needle biopsy FFPE specimens in patients with unresectable hepatocellular carcinoma treated with sorafenib. Oncotarget 2015;6:21636-21644.

-20 Togashi Y, Nishio K: [Kinase inhibitors and their resistance]. Nihon Rinsho 2015;73:1323-1329.

-21 Janku F, McConkey DJ, Hong DS, Kurzrock R: Autophagy as a target for anticancer therapy. Nat Rev Clin Oncol 2011;8:528-539.

22 Mizushima N: Autophagy: process and function. Genes Dev 2007;21:2861-2873.

23 David R: Metabolism: Keeping fit with autophagy. Nat Rev Mol Cell Biol 2012;13:136.

-24 Ryter SW, Cloonan SM, Choi AM: Autophagy: a critical regulator of cellular metabolism and homeostasis. Mol Cells 2013;36:7-16.

-25 Mizushima N, Levine B, Cuervo AM, Klionsky DJ: Autophagy fights disease through cellular self-digestion. Nature 2008;451:1069-1075.

-26 Parkhitko AA, Favorova 00, Henske EP: Autophagy: mechanisms, regulation, and its role in tumorigenesis. Biochemistry (Mosc) 2013;78:355-367.

-27 Tanida I: Autophagy basics. Microbiol Immunol 2011;55:1-11.

28 He C, Klionsky DJ: Regulation mechanisms and signaling pathways of autophagy. Annu Rev Genet 2009;43:67-93.

29 Yang Z, Klionsky DJ: Mammalian autophagy: core molecular machinery and signaling regulation. Curr Opin Cell Biol 2010;22:124-131.

-30 Mizushima N: The role of the Atg1/ULK1 complex in autophagy regulation. Curr Opin Cell Biol 2010;22:132-139.

-31 Yuan HX, Russell RC, Guan KL: Regulation of PIK3C3/VPS34 complexes by MTOR in nutrient stress-induced autophagy. Autophagy 2013;9:1983-1995.

-32 Orsi A, Polson HE, Tooze SA: Membrane trafficking events that partake in autophagy. Curr Opin Cell Biol 2010;22:150-156. 


\section{Cellular Physiology Cell Physiol Biochem 2017;44:716-727 \begin{tabular}{l|l|l} 
and Biochemistry 10.1159/000485285 & (c) 2017 The Author(s). Published by S. Karger AG, Basel \\
www.karger.com/cpb
\end{tabular}

33 Sou YS, Waguri S, Iwata J, Ueno T, Fujimura T, Hara T, Sawada N, Yamada A, Mizushima N, Uchiyama Y, Kominami E, Tanaka K, Komatsu M: The Atg8 conjugation system is indispensable for proper development of autophagic isolation membranes in mice. Mol Biol Cell 2008;19:4762-4775.

-34 Matsunaga K, Saitoh T, Tabata K, Omori H, Satoh T, Kurotori N, Maejima I, Shirahama-Noda K, Ichimura T, Isobe T, Akira S, Noda T, Yoshimori T: Two Beclin 1-binding proteins, Atg14L and Rubicon, reciprocally regulate autophagy at different stages. Nat Cell Biol 2009;11:385-396.

-35 Zhong Y, Wang QJ, Li X, Yan Y, Backer JM, Chait BT, Heintz N, Yue Z: Distinct regulation of autophagic activity by Atg14L and Rubicon associated with Beclin 1-phosphatidylinositol-3-kinase complex. Nat Cell Biol 2009;11:468-476.

-36 Sengupta S, Peterson TR, Sabatini DM: Regulation of the mTOR complex 1 pathway by nutrients, growth factors, and stress. Mol Cell 2010;40:310-322.

37 Manwani B, McCullough LD: Function of the master energy regulator adenosine monophosphate-activated protein kinase in stroke. J Neurosci Res 2013;91:1018-1029.

38 Shintani T, Klionsky DJ: Autophagy in health and disease: a double-edged sword. Science 2004;306:990995.

-39 White E, DiPaola RS: The double-edged sword of autophagy modulation in cancer. Clin Cancer Res 2009;15:5308-5316.

40 Eskelinen EL: The dual role of autophagy in cancer. Curr Opin Pharmacol 2011;11:294-300.

41 Guo JY, White E: Autophagy, Metabolism, and Cancer. Cold Spring Harb Symp Quant Biol 2016;81:73-78.

$>42$ Liu J, Fan L, Wang H, Sun G: Autophagy, a double-edged sword in anti-angiogenesis therapy. Med Oncol 2016;33:10.

43 Thorburn A: Autophagy and its effects: making sense of double-edged swords. PLoS Biol 2014;12:e1001967.

44 Thorburn A, Thamm DH, Gustafson DL: Autophagy and cancer therapy. Mol Pharmacol 2014;85:830-838.

45 Shi YH, Ding ZB, Zhou J, Hui B, Shi GM, Ke AW, Wang XY, Dai Z, Peng YF, Gu CY, Qiu SJ, Fan J: Targeting autophagy enhances sorafenib lethality for hepatocellular carcinoma via ER stress-related apoptosis. Autophagy 2011;7:1159-1172.

-46 Zhai B, Hu F, Jiang X, Xu J, Zhao D, Liu B, Pan S, Dong X, Tan G, Wei Z, Qiao H, Jiang H, Sun X: Inhibition of Akt reverses the acquired resistance to sorafenib by switching protective autophagy to autophagic cell death in hepatocellular carcinoma. Mol Cancer Ther 2014;13:1589-1598.

47 Shimizu S, Takehara T, Hikita H, Kodama T, Tsunematsu H, Miyagi T, Hosui A, Ishida H, Tatsumi T, Kanto T, Hiramatsu N, Fujita N, Yoshimori T, Hayashi N: Inhibition of autophagy potentiates the antitumor effect of the multikinase inhibitor sorafenib in hepatocellular carcinoma. Int J Cancer 2012;131:548-557.

48 Tai WT, Shiau CW, Chen HL, Liu CY, Lin CS, Cheng AL, Chen PJ, Chen KF: Mcl-1-dependent activation of Beclin 1 mediates autophagic cell death induced by sorafenib and SC-59 in hepatocellular carcinoma cells. Cell Death Dis 2013;4:e485.

49 Fischer TD, Wang JH, Vlada A, Kim JS, Behrns KE: Role of autophagy in differential sensitivity of hepatocarcinoma cells to sorafenib. World J Hepatol 2014;6:752-758.

-50 Ling S, Song L, Fan N, Feng T, Liu L, Yang X, Wang M, Li Y, Tian Y, Zhao F, Liu Y, Huang Q, Hou Z, Xu F, Shi L, Li Y: Combination of metformin and sorafenib suppresses proliferation and induces autophagy of hepatocellular carcinoma via targeting the mTOR pathway. Int J Oncol 2017;50:297-309.

-51 Yuan H, Li AJ, Ma SL, Cui LJ, Wu B, Yin L, Wu MC: Inhibition of autophagy signi fi cantly enhances combination therapy with sorafenib and HDAC inhibitors for human hepatoma cells. World J Gastroenterol 2014;20:4953-4962.

52 Luo T, Fu J, Xu A, Su B, Ren Y, Li N, Zhu J, Zhao X, Dai R, Cao J, Wang B, Qin W, Jiang J, Li J, Wu M, Feng G, Chen Y, Wang H: PSMD10/gankyrin induces autophagy to promote tumor progression through cytoplasmic interaction with ATG7 and nuclear transactivation of ATG7 expression. Autophagy 2016;12:1355-1371.

53 Wangensteen KJ, Wilber A, Keng VW, He Z, Matise I, Wangensteen L, Carson CM, Chen Y, Steer CJ, McIvor RS, Largaespada DA, Wang X, Ekker SC: A facile method for somatic, lifelong manipulation of multiple genes in the mouse liver. Hepatology 2008;47:1714-1724.

54 Keng VW, Tschida BR, Bell JB, Largaespada DA: Modeling hepatitis B virus X-induced hepatocellular carcinoma in mice with the Sleeping Beauty transposon system. Hepatology 2011;53:781-790. 


\section{Cellular Physiology Cell Physiol Biochem 2017;44:716-727

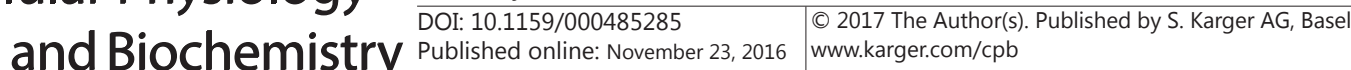 \\ Sun/Liu/Ming: Autophagy and Sorafenib Resistance in HCC}

55 Carlson CM, Frandsen JL, Kirchhof N, McIvor RS, Largaespada DA: Somatic integration of an oncogeneharboring Sleeping Beauty transposon models liver tumor development in the mouse. Proc Natl Acad Sci U S A 2005;102:17059-17064.

-56 Tward AD, Jones KD, Yant S, Cheung ST, Fan ST, Chen X, Kay MA, Wang R, Bishop JM: Distinct pathways of genomic progression to benign and malignant tumors of the liver. Proc Natl Acad Sci U S A 2007;104:14771-14776.

57 Calvisi DF, Wang C, Ho C, Ladu S, Lee SA, Mattu S, Destefanis G, Delogu S, Zimmermann A, Ericsson J, Brozzetti S, Staniscia T, Chen X, Dombrowski F, Evert M: Increased lipogenesis, induced by AKTmTORC1-RPS6 signaling, promotes development of human hepatocellular carcinoma. Gastroenterology 2011;140:1071-1083.

58 Ho C, Wang C, Mattu S, Destefanis G, Ladu S, Delogu S, Armbruster J, Fan L, Lee SA, Jiang L, Dombrowski F, Evert M, Chen X, Calvisi DF: AKT (v-akt murine thymoma viral oncogene homolog 1) and N-Ras (neuroblastoma ras viral oncogene homolog) coactivation in the mouse liver promotes rapid carcinogenesis by way of mTOR (mammalian target of rapamycin complex 1), FOXM1 (forkhead box M1)/ SKP2, and c-Myc pathways. Hepatology 2012;55:833-845.

59 Pitot HC, Dragan YP: Facts and theories concerning the mechanisms of carcinogenesis. FASEB J 1991;5:2280-2286.

60 Hacker HJ, Mtiro H, Bannasch P, Vesselinovitch SD: Histochemical profile of mouse hepatocellular adenomas and carcinomas induced by a single dose of diethylnitrosamine. Cancer Res 1991;51:1952-1958.

61 He L, Tian DA, Li PY, He XX: Mouse models of liver cancer: Progress and recommendations. Oncotarget 2015;6:23306-23322.

62 Wu FQ Fang T, Yu LX, Lv GS, Lv HW, Liang D, Li T, Wang CZ, Tan YX, Ding J, Chen Y, Tang L, Guo LN, Tang SH, Yang W, Wang HY: ADRB2 signaling promotes HCC progression and sorafenib resistance by inhibiting autophagic degradation of HIF1alpha. J Hepatol 2016;65:314-324.

63 Neufeld TP: TOR-dependent control of autophagy: biting the hand that feeds. Curr Opin Cell Biol 2010;22:157-168.

64 Kim YC, Guan KL: mTOR: a pharmacologic target for autophagy regulation. J Clin Invest 2015;125:25-32.

65 Asnaghi L, Bruno P, Priulla M, Nicolin A: mTOR: a protein kinase switching between life and death. Pharmacol Res 2004;50:545-549.

66 Liu LP, Ho RL, Chen GG, Lai PB: Sorafenib inhibits hypoxia-inducible factor-1alpha synthesis: implications for antiangiogenic activity in hepatocellular carcinoma. Clin Cancer Res 2012;18:5662-5671.

-67 Chen KF, Chen HL, Tai WT, Feng WC, Hsu CH, Chen PJ, Cheng AL: Activation of phosphatidylinositol 3-kinase/Akt signaling pathway mediates acquired resistance to sorafenib in hepatocellular carcinoma cells. J Pharmacol Exp Ther 2011;337:155-161.

68 Grahame Hardie D: AMP-activated protein kinase: a key regulator of energy balance with many roles in human disease. J Intern Med 2014;276:543-559.

-69 Novikova DS, Garabadzhiu AV, Melino G, Barlev NA, Tribulovich VG: AMP-activated protein kinase: structure, function, and role in pathological processes. Biochemistry (Mosc) 2015;80:127-144.

-70 Jing K, Song KS, Shin S, Kim N, Jeong S, Oh HR, Park JH, Seo KS, Heo JY, Han J, Park JI, Han C, Wu T, Kweon GR, Park SK, Yoon WH, Hwang BD, Lim K: Docosahexaenoic acid induces autophagy through p53/AMPK/ mTOR signaling and promotes apoptosis in human cancer cells harboring wild-type p53 Autophagy 2011;7:1348-1358.

-71 Ha J, Guan KL, Kim J: AMPK and autophagy in glucose/glycogen metabolism. Mol Aspects Med 2015;46:4662.

72 Fumarola C, Caffarra C, La Monica S, Galetti M, Alfieri RR, Cavazzoni A, Galvani E, Generali D, Petronini PG, Bonelli MA: Effects of sorafenib on energy metabolism in breast cancer cells: role of AMPK-mTORC1 signaling. Breast Cancer Res Treat 2013;141:67-78.

73 Tesori V, Piscaglia AC, Samengo D, Barba M, Bernardini C, Scatena R, Pontoglio A, Castellini L, Spelbrink JN, Maulucci G, Puglisi MA, Pani G, Gasbarrini A: The multikinase inhibitor Sorafenib enhances glycolysis and synergizes with glycolysis blockade for cancer cell killing. Sci Rep 2015;5:9149.

-74 Pignochino Y, Dell’Aglio C, Basirico M, Capozzi F, Soster M, Marchio S, Bruno S, Gammaitoni L, Sangiolo D, Torchiaro E, D’Ambrosio L, Fagioli F, Ferrari S, Alberghini M, Picci P, Aglietta M, Grignani G: The Combination of Sorafenib and Everolimus Abrogates mTORC1 and mTORC2 upregulation in osteosarcoma preclinical models. Clin Cancer Res 2013;19:2117-2131. 


\section{Cellular Physiology Cell Physiol Biochem 2017;44:716-727 \begin{tabular}{l|l|l} 
and Biochemistry & Dublished onlIne: November 23, 2016 & $\begin{array}{l}\text { (c) } 2017 \text { The Author(s). Published by S. Karger AG, Basel } \\
\text { www.karger.com/cpb }\end{array}$
\end{tabular}}

Sun/Liu/Ming: Autophagy and Sorafenib Resistance in HCC

75 Sun T, Li X, Zhang P, Chen WD, Zhang HL, Li DD, Deng R, Qian XJ, Jiao L, Ji J, Li YT, Wu RY, Yu Y, Feng GK, Zhu $\mathrm{XF}$ : Acetylation of Beclin 1 inhibits autophagosome maturation and promotes tumour growth. Nat Commun 2015;6:7215.

76 Germain M, Nguyen AP, Le Grand JN, Arbour N, Vanderluit JL, Park DS, Opferman JT, Slack RS: MCL-1 is a stress sensor that regulates autophagy in a developmentally regulated manner. EMBO J 2011;30:395-407.

77 Mukhopadhyay S, Panda PK, Sinha N, Das DN, Bhutia SK: Autophagy and apoptosis: where do they meet? Apoptosis 2014;19:555-566.

-78 Chen K, Rajewsky N: The evolution of gene regulation by transcription factors and microRNAs. Nat Rev Genet 2007;8:93-103.

79 Frankel LB, Lund AH: MicroRNA regulation of autophagy. Carcinogenesis 2012;33:2018-2025.

-80 Ding Z, Wang X, Schnackenberg L, Khaidakov M, Liu S, Singla S, Dai Y, Mehta JL: Regulation of autophagy and apoptosis in response to ox-LDL in vascular smooth muscle cells, and the modulatory effects of the microRNA hsa-let-7 g. Int J Cardiol 2013;168:1378-1385.

-81 Sermersheim MA, Park KH, Gumpper K, Adesanya TM, Song K, Tan T, Ren X, Yang JM, Zhu H: MicroRNA regulation of autophagy in cardiovascular disease. Front Biosci (Landmark Ed) 2017;22:48-65.

-82 Stiuso P, Potenza N, Lombardi A, Ferrandino I, Monaco A, Zappavigna S, Vanacore D, Mosca N, Castiello F, Porto S, Addeo R, Prete SD, De Vita F, Russo A, Caraglia M: MicroRNA-423-5p Promotes Autophagy in Cancer Cells and Is Increased in Serum From Hepatocarcinoma Patients Treated With Sorafenib. Mol Ther Nucleic Acids 2015;4:e233.

83 He C, Dong X, Zhai B, Jiang X, Dong D, Li B, Jiang H, Xu S, Sun X: MiR-21 mediates sorafenib resistance of hepatocellular carcinoma cells by inhibiting autophagy via the PTEN/Akt pathway. Oncotarget 2015;6:28867-28881.

84 Smyth MJ, Ngiow SF, Ribas A, Teng MW: Combination cancer immunotherapies tailored to the tumour microenvironment. Nat Rev Clin Oncol 2016;13:143-158.

-85 Lin J, Wu L, Bai X, Xie Y, Wang A, Zhang H, Yang X, Wan X, Lu X, Sang X, Zhao H: Combination treatment including targeted therapy for advanced hepatocellular carcinoma. Oncotarget 2016;7:71036-71051.

-86 Bareford MD, Park MA, Yacoub A, Hamed HA, Tang Y, Cruickshanks N, Eulitt P, Hubbard N, Tye G, Burow ME, Fisher PB, Moran RG, Nephew KP, Grant S, Dent P: Sorafenib enhances pemetrexed cytotoxicity through an autophagy-dependent mechanism in cancer cells. Cancer Res 2011;71:4955-4967.

87 Zhai B, Jiang X, He C, Zhao D, Ma L, Xu L, Jiang H, Sun X: Arsenic trioxide potentiates the anti-cancer activities of sorafenib against hepatocellular carcinoma by inhibiting Akt activation. Tumour Biol 2015;36:2323-2334.

-88 Lam W, Jiang Z, Guan F, Huang X, Hu R, Wang J, Bussom S, Liu SH, Zhao H, Yen Y, Cheng YC: PHY906(KD018), an adjuvant based on a 1800-year-old Chinese medicine, enhanced the anti-tumor activity of Sorafenib by changing the tumor microenvironment. Sci Rep 2015;5:9384.

89 Manov I, Pollak Y, Broneshter R, Iancu TC: Inhibition of doxorubicin-induced autophagy in hepatocellular carcinoma Hep3B cells by sorafenib--the role of extracellular signal-regulated kinase counteraction. FEBS J 2011;278:3494-3507.

-90 Steinman RM, Mellman IS, Muller WA, Cohn ZA: Endocytosis and the recycling of plasma membrane. J Cell Biol 1983;96:1-27.

91 Mizushima N, Yoshimori T, Levine B: Methods in mammalian autophagy research. Cell 2010;140:313-326.

92 Giannini G, Cabri W, Fattorusso C, Rodriquez M: Histone deacetylase inhibitors in the treatment of cancer: overview and perspectives. Future Med Chem 2012;4:1439-1460.

-93 Maruthur NM, Tseng E, Hutfless S, Wilson LM, Suarez-Cuervo C, Berger Z, Chu Y, Iyoha E, Segal JB, Bolen S: Diabetes Medications as Monotherapy or Metformin-Based Combination Therapy for Type 2 Diabetes: A Systematic Review and Meta-analysis. Ann Intern Med 2016;164:740-751.

94 Ben Sahra I, Tanti JF, Bost F: The combination of metformin and 2 deoxyglucose inhibits autophagy and induces AMPK-dependent apoptosis in prostate cancer cells. Autophagy 2010;6:670-671.

$\$ 95$ Racanelli AC, Rothbart SB, Heyer CL, Moran RG: Therapeutics by cytotoxic metabolite accumulation: pemetrexed causes ZMP accumulation, AMPK activation, and mammalian target of rapamycin inhibition. Cancer Res 2009;69:5467-5474.

-96 Rothbart SB, Racanelli AC, Moran RG: Pemetrexed indirectly activates the metabolic kinase AMPK in human carcinomas. Cancer Res 2010;70:10299-10309. 